\title{
PEMILIHAN BAHASA DALAM IKLAN "ORANG PINTAR MINUM TOLAK ANGIN" VS "ORANG BEJO MINUM BITANG TOEJOEH MASUK ANGIN" DALAM ETIKA PERIKLANAN
}

\author{
Zahra Nabila Alfira Insyraa \\ Mahasiswa Prodi Manajeman FE Universitas Sultan Agung Semarang \\ zahranabila010301@gmail.com
}

\begin{abstract}
ABSTRAK
Banyak prespektif tentang pemilihan Bahasa dalam etika periklanan, dan juga penonton harus bisa membedakan dan mengkritisi iklan tersebut. Iklan dengan tagline "Orang pintar minum tolak angin" di luncurkan Perusahan PT SIDOMUNCUL yang berdiri dari sebuah industri rumah tangga pada tahun 1940. Dan sudah di tayangkan pertama kali di televisi tahun 2000, dan sudah menghipnotis masyrakat dengan obat herbal yang berbentuk cairan yang mudah di bawa kemana-mana untuk mengatasi masuk angin. Sedangkan Iklan dengan tagline "Orang bejo minum bintang toejoeh masuk angin"yang di mana di produksi oleh PT BINTANG TOEJOEH yang berdiri pada tahun 1946 di Garut dan di tayangkan pada tahun 2012. Dan yang menjadi banyak pertimbangan itu dengan menjadi ciri khas tagline masing masing yaitu dan salah satunya kalimat pada "Orang bejo lebih untung dari orang pintar" yang menyinggung iklan pada kalimat "Orang pintar minum tolak angin" yang digunakan PT Sidomuncul. Pembahasan dua iklan ini dilihat dari presfektif masyrakat dan Undang-undang Nomor 32 Tahun 2002 tentang penyiaran dan juga dilihat dari etika yang seharusnya dilakukan perusahaan dan dengan pemilihan Bahasa dalam periklanan yang benar dalam mengiklankan produknya.
\end{abstract}

Kata kunci: Pemilihan Bahasa, etika periklanan televisi

\section{PENDAHULUAN}

Banyak masyarakat Indonesia mempersepsikan bahwa jamu itu hanya diminum untuk masyarakat tradisonal. Maka dari ini menyebabkan PT SIDOMUNCUL mau mengubah pendapat tersebut. Pada tahun 2000, PT SIDOMUNCUL pertama kali mengiklankan dan memperkenalkan obat herbal berupa cairan yang diperkenalkan dengan nama Tolak angin, dan obat herbal ini dapat diminum oleh semua kalangan, dan para pengiklan pun menggunakan aktris dan aktors serta penyanyi Indonesia untuk mengiklankan produknya, seperti Agnes Mo, Lula kamal, Abimayu, Sophia Latjuba, dan di beberapa produk yang diluncukan PT SIDOMUNCUL juga seringkali menggaet para penyanyi, actor, aktris papan atas untuk mengiklankan produknya tersebut. PT SIDOMUNCUL ini juga menjadikan obat herbal untuk menyembuhkan masuk angin yang berupa cairan saat ini banyak di minati oleh semua kalarangan masyarakat.(Tolak angin, 2013).

Sebagai konsumen seharusnya masyarakat mengerti hak-hak konsumen. Sebagaimana yang tertera dalam 6 Pasal 1 angka 6 Undang-Undang Nomor 8 Tahun 1999, hak konsumen untuk mengakses informasi dari penayangan iklan sudah diatur dengan tegas, yaitu berupa informasiinformasi yang benar, jelas, dan jujur mengenai kondisi dan jaminan barang dan/ atau jasa. Ketiga muatan informasi (benar, jelas, dan jujur), yang wajib diberikan pelaku usaha, secara hukum mutlak harus diinformasikan. Meskipun di sisi lain, ukuran-ukuran dari ketiga muatan informasi tersebut tidak begitu jelas. Persoalan ukuran diperkenankan atau dilarang, secara hukum menjadi hal yang sensitif bagi dunia usaha, agar dapat bersaing dalam iklan dan promosi secara sehat dan fair. Kewajiban Pelaku Usaha untuk menginformasikannya. Akan tetapi, sering kali dalam prakteknya pelaku usaha tidak menginformasikan dalam iklan, baik cetak maupun elektronik, tentang kondisi yang sebenarnya dari produk yang ditawarkan. 


\section{METODE PENEITIAN}

Pendekatan yang di lakukan dalam penelitian ini adalah pendekatan kualitatif yang sifatnya deskriptif. Dalam metode yang dilakukan ini untuk memperoleh gambaran secara sistematis fakta dan karakteristik objek dan subjek yang diteliti. Dalam hal ini penelitian ini akan memberikan pemahaman dan deskripsi tentang pembangunan citra merek dan agar masyarakat bisa berpikir kritis pada iklan Antangin dan Bintang Toejoe Masuk Angin yang dibangun dengan media iklan televisi untuk mencari nama dalam penggunakaan Bahasa dalam pengiklanan di televisi untuk mendukukng metode dokumentasi.

Metode penelitian dan pengumpulan data yang digunakan dalam penelitian ini menggunakan data sekunder yang mana diambil dari data kepustakaan dan video-video iklan dari jenis produk iklan dari waktu kewaktu, dan juga agar memberikan deskripsi dapat mendapatkan isi dari pesan iklan yang disampaikan untuk membentuk brand image dari produk Jamu herbal ini dengan memberikan tagline yang membuat masyrakat tertarik, terlebih lagi ini bisa dikonsumsi dari semua kalangan.

Jamu merupakan warisan budaya Bangsa Indonesia yang diwariskan secara turun-temurun dan dari generasi ke generasi. Meski zaman makin modern, konsumsi jamu di kalangan masyarakat Indonesia tak surut, jamu juga dipakai sebagai pengobatan tradisonal yang dipercaya dan lebih bagus dari pada mengonsumsi obat,

\section{HASIL DAN PEMBAHASAN Pemilihan Bahasa Periklanan}

Dalam situasi pemilihan kebahasaan menyediakan beberapa Bahasa atau variasi Bahasa dalam masyarakat. Seseorang harus melakukan pemilihan bahasa yang tepat untuk berbicara dengan dengan mitra, mau melakukan bisnis ataupun tidak harus mengolah semua kata yang baik dan benar. Hal ini disebabkan adanya penyesuaian yang dilakukan penutur untuk memenuhi kebutuhan berbahasa.

Mengenai Undang-undang Republik Indonesia No. 24 tahun 1997 tentang penyiaran Pasal 42 Siaran iklan niaga dilarang memuat: a). Promosi yang berkaitan dengan ajaran suatu agama atau aliran tertentu, ajaran politik atau idiologi tertentu, promosi pribadi, golongan atau kelompok tertentu; b). Promosi barang dan jasa yang berlebihan-lebihan dan yang menyesatkan, baik mengenai mutu, asal isi, ukuran, sifat; c). Iklan minuman keras dan sejenisnya, bahan/zat adiktif serta yang menggambarkan penggunaan rokok, dan d). Hal-hal yang bertentangan dengan rasa kesusilaan masyarakat.

Dalam melalukan pemilihan Bahasa yang benar untuk media cetak apalagi televisi harus di perhatikan dengan baik, karena akan disiarkan yang dilakukan dan semua segala umur akan melihatnya. Tetapi banyak kasus banyak brand menyinggung brand lain.

\section{Siaran iklan Oang Pintar Minum Tolak Angin vs Orang Bejo Minum Bintang Toejoe masuk Angin}

Yang menjadi banyak perbincangan yaitu ketika iklan pertama Bintang Toejoe Masuk Angin diluncurkan pertengahan 2012 lalu, banyak menuai kritikan di masyarakat, dia memberi tagline "Orang Bejo Minum Bintang Toejoe Masuk Angin " seolah-olah menyinggung produk dari PT Sidomuncul Tolak Angin yang sudah lebih dulu mengiklankan produknya dengan tagline "Orang Pintar Minum tolak Angin”. Karena Pintar belum tentu beruntung dan bejo pun belum tentu pintar, Orang pintar akan kalah dengan orang bejo dan ada penekanan kata di tagline BTMA Masuk angin minum "Bintang Toejoe Masuk Angin" dan masyarakat banyak dibuat bingung dengan ini.

\section{Siaran iklan}

Etika periklanan adalah ukuran kewajaran nilai dan kejujuran didalam sebuah iklan. Menurut Persatuan Perusahaan Periklanan Indoneasia (P3I), etika periklanan adalah seperangkat norma dan padan yang mesti diikuti oleh para politis periklanan dalam mengemas dan menyebarluaskan pesan 
iklan kepada khalayak ramai baik melalui media massa maupn media ruang. Menurut EPI (Etika Pariwara Indonesia), etika periklanan adalah ketentuan-ketentuan normatif yang menyangkut profesi dan usaha periklanan yang telah disepakati untuk dihormati, ditaati, dan ditegakkan oleh semua asosiasi dan lembaga pengembangannya,

Media dalam penyampaian suatu produk seperti iklan yang disiarkan di televisi penyampaian pesan berupa gambar yang menggunakan artis dan suara sangat besar pengaruhnya dalam menyebarkan informasinya, media sebagai intuisi tentunya mempunyai makna dan tujuannya sendiri dalam penyampaian pesan, tetapi dengan kata lain tidak ada SARA tidak ada menjatuhkan produk lain maupun menjelek-jelekkan produk lain.

\section{Akibat Pembentukan Opini di masyarakat melalui persepsi pengiklanan. Serta pembelajaran dalam dunia pengiklanan}

Dalam hal ini tolak angin sangat dan lebih memilih model untuk melakukan pemasaran produknya yaitu menggunakan tokoh politik dibandingkan selebriti, ya salah satunya tokoh politik, mentri BUMN Dahlan Iskan, dan mereka mengambil lokasi syuting iklannya yaitu dilakukan di luar negeri yaitu di Eropa maupun di Amerika, dan juga dengan begini ada pengaruh dengan menggaet tokoh politik untuk konsumen membeli Tolak Angin

Tidak banyak juga iklan-iklan yang mengandung unsur penipuan Dalam hal ini Rampen (2014) menjelaskan:

"di Indonesia iklan-iklan yang cenderung menyesatkan bahkan mengandung unsur-unsur penipuan juga banyak dijumpai, baik melalui media cetak maupun media elektronik. Pada prakteknya iklan-iklan yang tidak jujur dan tidak bertanggung jawab masih tetap berjalan dan risiko dari iklan tersebut tetap dipikul oleh pihak konsumen. Iklan dalam segala bentuknya mengikat para pihak tersebut dengan segala akibat hukumnya. Iklan bagi konsumen merupakan alat atau salah satu sumber informasi mengenai sesuatu barang. Besarnya peranan iklan sebagai alat informasi di satu pihak harus pula diikuti dengan pengawasan terhadap mutu iklan di pihak lain, sehingga iklan tidak menjadi suatu produk jasa informasi yang bersifat tidak aman (unsafe product) dan mengandung unsur itikad tidak baik (unfair behavior)".

\section{SIMPULAN}

\section{Simpulan}

Iklan merupakan salah satu media yang menyampaikan pesan, bisa berupa produk maupun kata-kata, dan penyampainnya itu melibatkan beberapa instansi, bisa di pertelevisian ataupun media cetak lainnya. Sama hal yang dilakukan dengan 2 produk dari perusahaan besar pruduk herbal yaitu PT SIDOMUNCUL dan PT BNTANG TOEJOEH dengan produk unggulannya masing-masing tetapi pesan dengan taglinenya kadang cenderung merendahkan produk dari salah satunya instansi lainnya, karena tata kebahasaan dalam menampilkan iklan harus ditata, dan sudah ada undang-undang yang membuat etika periklanan untuk menjaga keharmonisan dan juga diperlukan dapat memperkuat pesan iklan dalam membangun citra produk tanpa merendahkan.

\section{DAFTAR PUSTAKA}

Tolak angin. (2013). http://sidomuncul67.blogspot.co.id/p/blog-page_3753.html. file://C:/Users/ACER/Downloads/Documents/vol\%2018\%20no\%201\%20jurnal\%20ilmiah\% 20kajian\%20sosial\%20dan\%20budaya.pdf

Undang-Undang Republik Indonesia Nomor 32 Tahun 2002 tentang Penyiaran. Undang Undang Republik Indonesia Nomor 24 Tahun 1997 tentang Penyiaran. https://fahmirezamathovani.wordpress.com/2015/11/01/etika-dalam-periklanan/ 
file://C:/Users/ACER/Downloads/Documents/2102.pdf

Ningrum, A. A. W. (2014). Pengaruh penggunaan tokoh politik (Dahlan Iskan) sebagai endorser terhadap minat pembelian produk tolak angin (Studi pada mahasiswa Fakultas Ekonomi Unesa). Jurnal Pendidikan Tata Niaga (JPTN), 2(3). 